\title{
DETERMINANTS OF KNOWLEDGE ABOUT COVID-19 TRANSMISSION PREVENTIONAND ANTENATAL CARE VISIT IN GRESIK, EAST JAVA
}

\author{
Endah Mulyani, Sulastri, Zahrotul Hidayati, Khaulah Mujahidah \\ Midwifery Program, Faculty of Health, Universitas Muhammadiyah Gresik
}

\begin{abstract}
Background: Covid-19 is a highly infectious disease with a higher risk to suffer severe health complications, especially for people with pre-existing medical conditions. Pregnant women must prevent the risk of disease transmission as the probability of adverse birth outcomes. This study aimed to examine the determinants of Covid-19 transmission and prevention knowledge among pregnant women in Gresik, East Java.

Subjects and Method: A cross-sectional study was conducted in Gresik, East Java in July 2020. A total of 46 pregnant women was selected for this study. The dependent variable was level of Covid-19 transmission and prevention knowledge among pregnant women. The independent variables were age, level of education, carrier status, and information media. The study subjects were selected by total sampling method. The data were collected by using questionnaires. Data were analyzed by multiple logistic regression.

Results: Level of Covid-19 transmission and prevention knowledge among pregnant women increased with maternal age $(\mathrm{OR}=8.00 ; 95 \% \mathrm{CI}=1.54$ to $41.49 ; \mathrm{p}=0.013)$, level of education $(\mathrm{OR}=13.00$; $95 \% \mathrm{CI}=2.35$ to $71.84 ; \mathrm{p}=0.003)$, and information media $(\mathrm{OR}=$ $37.75,95 \% \mathrm{CI}=4.41$ to $322.85 ; \mathrm{p}=0.001$ ). Level of Covid -19 transmission and prevention knowledge among pregnant women decreased with maternal carrier status $(\mathrm{OR}=0.11 ; 95 \%$ $\mathrm{CI}=0.03$ to $0.43 ; \mathrm{p}=0.032$ ).

Conclusion: Covid-19 transmission and prevention knowledge among pregnant women increase with maternal age, level of education, and information media while decreasing with maternal carrier status.
\end{abstract}

Keywords: Covid-19 transmission, prevention, knowledge, education, information media

Correspondence:

Endah Mulyani. Midwifery Program, Faculty of Health, Universitas Muhammadiyah Gresik. Jl. Proklamasi No.54 Trat, Gresik. Email: endahmulyani@umg.ac.id. Mobile: +6281252184499 .

The $7^{\text {th }}$ International Conference on Public Health

Solo, Indonesia, November 18-19, 2020 | 76 https://doi.org/10.26911/the7thicph.01.31 